\title{
Effect of partial supplementation of sun-dried Azolla as a protein source on the immunity and antioxidant status of commercial broilers
}

\author{
Biswal Chichilichi ${ }^{1}$, G. P. Mohanty ${ }^{1}$, S. K. Mishra ${ }^{2}$, C. R. Pradhan ${ }^{1}$, N. C. Behura ${ }^{3}$, A. Das ${ }^{2}$ and K. Behera ${ }^{1}$
}

1. Department of Livestock Production and Management, College of Veterinary Science \& Animal Husbandry, Orissa University of Agriculture and Technology, Bhubaneswar, Odisha, India; 2. Department of Animal Nutrition, College of Veterinary Science \& Animal Husbandry, Orissa University of Agriculture and Technology, Bhubaneswar, Odisha, India; 3. Postgraduate Department of Poultry Science, College of Veterinary Science \& Animal Husbandry, Orissa University of Agriculture and Technology, Bhubaneswar, Odisha, India.

Corresponding author: Biswal Chichilichi, e-mail: dr.biswalchichilichi@gmail.com, GPM: gpmouat@rediffmail.com, SKM: sumantkmishra@gmail.com, CRP: pradhancr@gmail.com, NCB: kvk_semiliguda@yahoo.co.in, AD: das.abinas@ gmail.com, KB: kumaresh.behera@gmail.com

Received: 08-05-2015, Revised: 19-08-2015, Accepted: 24-08-2015, Published online: 23-09-2015

doi: 10.14202/vetworld.2015.1126-1130 How to cite this article: Chichilichi B, Mohanty GP, Mishra SK, Pradhan CR, Behura NC, Das A, Behera K (2015) Effect of partial supplementation of sun-dried Azolla as a protein source on the immunity and antioxidant status of commercial broilers, Veterinary World 8(9): 1126-1130.

\begin{abstract}
Aim: The present study was conducted to evaluate the effect of partial supplementation of sun-dried Azolla as a protein source on the immunity of commercial broilers in coastal Odisha.

Materials and Methods: A 180 day-old broiler chicks were distributed in six dietary treatments viz. $\mathrm{C}_{1}$ : Basal diet, $\mathrm{C}_{2}$ : Basal diet + enzyme, $\mathrm{T}_{1}$ : Basal diet $+5 \%$ protein from Azolla, $\mathrm{T}_{2}$ : Basal diet $+5 \%$ protein from Azolla + enzyme, $\mathrm{T}_{3}$ : Basal diet $+10 \%$ protein from Azolla, and $\mathrm{T}_{4}$ : Basal diet $+10 \%$ protein from Azolla + enzyme. Cutaneous basophilc hypersensitivity $(\mathrm{CBH})$ and humoral immunity response were determined at the $38^{\text {th }}$ day of age. At $42^{\text {nd }}$ day, the weight of lymphoid organs, an antioxidant enzyme, and lipid peroxidation activity were determined.

Results: The $\mathrm{CBH}$ response did not differ significantly among the treated groups, but the sheep red blood cells response was significantly higher in $\mathrm{T}_{4}$. The weight of lymphoid organs or immune organs of all the treated groups did not differ significantly $(\mathrm{p}>0.05)$. The erythrocyte catalase level of $\mathrm{T}_{4}$ group was found to be significantly higher than rest of the treated groups except $\mathrm{T}_{3}$.

Conclusion: It may be concluded that supplementation of Azolla at $10 \%$ of dietary protein requirement along with enzyme supplementation in an isonitrogenous diet showed a better immune response in broilers.
\end{abstract}

Keywords: antioxidant, Azolla, broiler, immune response.

\section{Introduction}

Azolla is, a protein rich aquatic plant, containing almost all essential amino acids, carotene, and several growth promoter intermediaries, minerals such as calcium, phosphorus magnesium, potassium, iron, and copper [1], and certain compounds such as carotenoids, bio-polymers, and probiotics [2]. In case of commercial broiler chickens, Azolla can be efficiently used as a feed ingredient in the form of sun-dried and ground Azolla meal [3].

Azolla meal can partially replace the dietary protein sources up to $5-10 \%$ without any adverse effect on the health and performance of the birds [4]. Inclusion of Azolla in the poultry diet helps in the economization of production cost; and thus, increasing the net profit [1]. Similar findings have been observed in the case of quails with optimum displacement level of Azolla restricted to 5\% [5]. The high carotene content of Azolla is responsible for its immune-potentiating effect in poultry birds [1]. In

Copyright: The authors. This article is an open access article licensed under the terms of the Creative Commons Attributin License (http:// creativecommons.org/licenses/by/2.0) which permits unrestricted use, distribution and reproduction in any medium, provided the work is properly cited. non-ruminants, essential amino acids, linoleic acid, vitamin $A$, folic acid, vitamin $B_{6}$, vitamin $B_{12}$, vitamin $\mathrm{C}$, vitamin $\mathrm{E}$, zinc, copper, iron, and selenium affect one or more indices of immunity [6]. Use of Azolla as an antibacterial and antioxidant agent in complementary and alternate medicine [7] had been recommended due to its high phenolic and flavonoid content [8]. Antioxidant activity of Azolla had been successfully demonstrated in Swiss albino mice [9].

With consideration of the presence of essential nutrients in Azolla, the present experiment was planned with the objective of studying the effect of partial supplementation of sun-dried Azolla as a protein source on the immunity of commercial broilers.

\section{Materials and Methods}

\section{Ethical approval}

The experiment followed the guidelines of Institutional Animal Ethics Committee.

\section{Study area}

The experiment was conducted on commercial broilers reared in the Poultry Farm in Department of Poultry Science, College of Veterinary Sciences and 
Animal Husbandry, Orissa University of Agriculture and Technology, Bhubaneswar, Odisha.

\section{Experimental birds}

The 180 day-old broiler chicks were distributed randomly in six dietary treatments with three replications. The six dietary treatments were: $\mathrm{C}_{1}$ : Basal diet, $\mathrm{C}_{2}$ : Basal diet + enzyme, $\mathrm{T}_{1}$ : Basal diet $+5 \%$ dietary protein from Azolla, $\mathrm{T}_{2}$ : Basal diet $+5 \%$ dietary protein from Azolla + enzyme, $\mathrm{T}_{3}$ : Basal diet $+10 \%$ dietary protein from Azolla, and $\mathrm{T}_{4}$ : Basal diet $+10 \%$ dietary protein from Azolla + enzyme. The enzyme used in the study was containing cellulase, xylanase, pectinase, and phytase. The experiment continued up to $6^{\text {th }}$ week of age. The chemical composition of Azolla meal, ingredient composition and chemical composition of the experimental diet are provided in Tables- 1, 2 and 3, respectively.

\section{Evaluation of immunological parameters}

At $38^{\text {th }}$ day of age, two birds from each replicate in each dietary treatment were injected intradermally in the comb with $100 \mu \mathrm{g}$ of phytohemaglutinin-P in $0.1 \mathrm{ml}$ of normal saline to measure the cell-mediated

Table-1: Chemical composition of Azolla meal.

\begin{tabular}{lc}
\hline Nutrients & Percentage \\
\hline Dry matter & 91.03 \\
Crude protein & 25.42 \\
Crude fiber & 14.22 \\
Ether extract & 2.58 \\
Total ash & 18.75 \\
NFE & 39.02 \\
Calcium & 1.12 \\
Phosphorus & 0.53 \\
Zinc (ppm) & 159.1 \\
Copper (ppm) & 7.35 \\
Manganese (ppm) & 84.2 \\
Iron (ppm) & 284.7 \\
\hline
\end{tabular}

NFE=Nitrogen free extract

Table-2: Ingredient composition of the experimental diet.

\begin{tabular}{lcccccc}
\hline Ingredients & $\mathbf{C}_{\mathbf{1}}$ & $\mathbf{C}_{\mathbf{2}}$ & $\mathbf{T}_{\mathbf{1}}$ & $\mathbf{T}_{\mathbf{2}}$ & $\mathbf{T}_{\mathbf{3}}$ & $\mathbf{T}_{\mathbf{4}}$ \\
\hline Starter ration & & & & & & \\
$\quad$ Maize & 55.0 & 55.0 & 54.0 & 54.0 & 50.3 & 50.3 \\
Soybean meal & 39.5 & 39.5 & 37.9 & 37.9 & 36.0 & 36.0 \\
De-oiled rice bran & 2.5 & 2.5 & 0.0 & 0.0 & 0.0 & 0.0 \\
Oil & 0.0 & 0.0 & 0.5 & 0.5 & 1.5 & 1.5 \\
Azolla & 0.0 & 0.0 & 4.6 & 4.6 & 9.2 & 9.2 \\
$\quad$ Mineral mixture & 3.0 & 3.0 & 3.0 & 3.0 & 3.0 & 3.0 \\
$\quad$ and common salt & & & & & & \\
Total & 100 & 100 & 100 & 100 & 100 & 100 \\
Enzyme & - & + & - & + & - & + \\
Finisher ration & & & & & & \\
$\quad$ Maize & 60.0 & 60.0 & 60.0 & 60.0 & 57.25 & 57.25 \\
$\quad$ Soybean meal & 31.0 & 31.0 & 29.5 & 29.5 & 28.0 & 28.0 \\
De-oiled rice bran & 5.25 & 5.25 & 2.5 & 2.5 & 2.0 & 2.0 \\
$\quad$ Oil & 0.75 & 0.75 & 1.0 & 1.0 & 1.75 & 1.75 \\
$\quad$ Azolla & 0.0 & 0.0 & 4.0 & 4.0 & 8.0 & 8.0 \\
$\quad$ Mineral mixture & 3.0 & 3.0 & 3.0 & 3.0 & 3.0 & 3.0 \\
$\quad$ and common salt & & & & & & \\
Total & 100 & 100 & 100 & 100 & 100 & 100 \\
Enzyme & - & + & - & + & - & + \\
\hline
\end{tabular}

immune (CMI) response by cutaneous basophilc hypersensitivity $(\mathrm{CBH})$ test [10]. The thickness of comb was measured using digital caliper before inoculation and $24 \mathrm{~h}$ post inoculation, and $\mathrm{CBH}$ response was calculated as per Soni et al. [11]. At $38^{\text {th }}$ day, the measure of humoral immunity was carried out as per the method described by Abdallah et al. [12]. At $6^{\text {th }}$ week, three birds from each treatment were slaughtered and the weights of bursa, thymus, and spleen were recorded. About $3 \mathrm{ml}$ blood, for assessing the antioxidant indices, was collected in sterilized microcentrifuge tubes containing acid citrate dextrose (citric acid $8.0 \mathrm{~g}$, sodium citrate $22.0 \mathrm{~g}$, and dextrose $25.0 \mathrm{~g}$ and volume made to $1 \mathrm{~L}$ in distilled water) at $0.15 \mathrm{ml} / \mathrm{ml}$ blood as anticoagulant. The blood samples were centrifuged at $3000 \mathrm{rpm}$ for $10 \mathrm{~min}$ at $4^{\circ} \mathrm{C}$ and then the plasma and buffy coat were separated. The resulting erythrocyte pellet was washed thrice with phosphate buffer saline (PBS; pH 7.4; disodium hydrogen phosphate $13.65 \mathrm{~g}$, sodium dihydrogen phosphate $2.43 \mathrm{~g}$, and sodium chloride $10 \mathrm{~g}$ dissolved in $800 \mathrm{ml}$ distilled water, $\mathrm{pH}$ adjusted to 7.4 and volume made to $1 \mathrm{~L}$ ) as per Yagi et al. [13]. Red blood cell (RBC) diluted to 1:1 in PBS was used for the estimation of hemoglobin. For the estimation of catalase $1 \mathrm{ml}$ of the 1:1 diluted RBCs in PBS were mixed with $9 \mathrm{ml}$ distilled water to prepare hemolysate of 1:20 dilution. Erythrocyte catalase was assayed in erythrocytes by the spectrophotometric method as described by Bergmeyer [14]. The lipid peroxide level in the RBC hemolysate was determined by the method of Placer et al. [15].

\section{Statistical analysis}

The data from the experiment were subjected to statistical analysis as per the methods suggested by Snedecor and Cochran [16].

\section{Results}

\section{CBH and humoral immunity response}

The $\mathrm{CBH}$ response and antibody titers $\left(\log _{2}\right)$ against sheep RBCs (SRBC) inoculation at $6^{\text {th }}$ week of age of broiler chicks is presented in Table-4. The $\mathrm{CBH}$ response did not differ significantly among the treated groups. However, the SRBC response was significantly higher in $\mathrm{T}_{4}$ than that of other treated groups. The SRBC response of the birds of $T_{2}$ was significantly higher than that of $\mathrm{C}_{1}$ but did not differ significantly $(p>0.05)$ from other treated groups except $\mathrm{T}_{4}$.

\section{Lymphoid organs}

The weights of lymphoid organs (percentage of live weight) of Vencobb broiler chicks under different dietary treatments are presented in Table-5. The average weights of lymphoid organs viz. spleen, bursa, and thymus-expressed as percentage of live weight of 6 weeks old broiler chicks ranged from $0.084 \pm 0.007\left(\mathrm{C}_{1}\right)$ to $0.184 \pm 0.009\left(\mathrm{~T}_{2}\right), 0.091 \pm 0.022\left(\mathrm{C}_{2}\right)$ to $0.194 \pm 0.058\left(\mathrm{~T}_{3}\right)$, and $0.329 \pm 0.033\left(\mathrm{C}_{2}\right)$ to $0.577 \pm 0.152\left(\mathrm{~T}_{3}\right)$, respectively. 
The relative weight of spleen of broilers in T2 was numerically higher than all the other treatments. The percent weight of bursa and thymus were found to be the highest in the birds of treatment $T_{3}$. No significant $(p>0.05)$ difference was observed on the above parameters between the treated groups. The average weight (percentage of live weight) of liver which has got some role in immunity, ranged from $1.896 \pm 0.094$ $\left(\mathrm{C}_{1}\right)$ to $2.403 \pm 0.152\left(\mathrm{~T}_{1}\right)$ and showed insignificant $(\mathrm{p}>0.05)$ difference between the groups.

The weight of lymphoid organs or immune organs of all the treated groups did not differ significantly $(\mathrm{p}>0.05)$. Supplement of dietary protein from Azolla at 5\% or $10 \%$ level had no significant effect on the weight of lymphoid organs. Furthermore, enzyme supplementation had no effect on spleen, bursa, and thymus gland relative weights when compared with chick groups fed on the same diet without enzyme supplementation.

\section{Antioxidant status}

The antioxidant enzyme and lipid peroxidation activity in Vencobb broiler birds under different dietary treatments are presented in Table-6. Erythrocyte catalase activity (units/mg of hemoglobin) values of the birds at $6^{\text {th }}$ week of age were $1.27 \pm 0.04,1.34 \pm 0.03$, $1.90 \pm 0.07, \quad 2.05 \pm 0.20, \quad 2.94 \pm 0.07$, and $3.13 \pm 0.05$ in the treatments $\mathrm{C}_{1}, \mathrm{C}_{2}, \mathrm{~T}_{1}, \mathrm{~T}_{2}, \mathrm{~T}_{3}$, and $\mathrm{T}_{4}$, respectively. Erythrocyte catalase activity was significantly $(\mathrm{p}<0.05)$ higher in $\mathrm{T}_{3}$ and $\mathrm{T}_{4}$ groups compared to all other groups.

The erythrocyte malondialdehyde (MDA) levels (nmol MDA/mg of hemoglobin) of 6-week-old broiler birds under treatments $\mathrm{C}_{1}, \mathrm{C}_{2}, \mathrm{~T}_{1}, \mathrm{~T}_{2}, \mathrm{~T}_{3}$ and $\mathrm{T}_{4}$ were $2.01 \pm 0.15,1.93 \pm 0.03,1.95 \pm 0.16,1.93 \pm 0.12$, $1.97 \pm 0.14$, and $1.92 \pm 0.07$, respectively. The values showed insignificant $(\mathrm{p}>0.05)$ difference among the treatment groups with numerically highest and lowest value represented by treatment $\mathrm{C}_{1}$ and $\mathrm{T}_{4}$, respectively.

Table-3: Chemical composition (percentage of dry matter basis) of experimental diet.

\begin{tabular}{lccccccc}
\hline Nutrient & \multicolumn{3}{c}{ Starter ration } & & \multicolumn{3}{c}{ Finisher ration } \\
\cline { 2 - 4 } & $\mathbf{C}_{\mathbf{1}} / \mathbf{C}_{\mathbf{2}}$ & $\mathbf{T}_{\mathbf{1}} / \mathbf{T}_{\mathbf{2}}$ & $\mathbf{T}_{\mathbf{3}} / \mathbf{T}_{\mathbf{4}}$ & & $\mathbf{C}_{\mathbf{1}} / \mathbf{C}_{\mathbf{2}}$ & $\mathbf{T}_{\mathbf{1}} / \mathbf{T}_{\mathbf{2}}$ & $\mathbf{T}_{\mathbf{3}} / \mathbf{T}_{\mathbf{4}}$ \\
\hline Moisture & 11.0 & 12.2 & 12.8 & & 13.14 & 12.90 & 13.25 \\
Crude protein & 23.17 & 23.28 & 23.15 & & 20.14 & 20.08 & 20.12 \\
Ether extract & 1.05 & 1.38 & 1.53 & & 1.57 & 1.80 & 2.01 \\
Crude fiber & 4.01 & 4.58 & 4.92 & & 4.03 & 4.30 & 4.86 \\
Total ash & 6.34 & 7.44 & 7.87 & & 6.37 & 7.21 & 7.86 \\
NFE & 65.43 & 63.32 & 62.53 & & 67.89 & 66.61 & 65.15 \\
Calcium & 0.92 & 1.08 & 1.14 & & 0.82 & 0.91 & 0.91 \\
Available phosphorus & 0.48 & 0.51 & 0.50 & & 0.53 & 0.51 & 0.54 \\
Metabolizable energy*(Kcal/kg) & 2800.50 & 2803.42 & 2809.26 & & 2900.00 & 2899.78 & 2902.21 \\
\hline
\end{tabular}

NFE=Nitrogen free extract

Table-4: SRBC and CBH response of broiler chicks at 6 weeks of age.

\begin{tabular}{lccccccc}
\hline $\begin{array}{l}\text { Parameters } \\
\text { (unit) }\end{array}$ & \multicolumn{9}{c}{ Treatments } & P value \\
\cline { 2 - 7 } & $\mathbf{C}_{\mathbf{1}}$ & $\mathbf{C}_{\mathbf{2}}$ & $\mathbf{T}_{\mathbf{1}}$ & $\mathbf{T}_{\mathbf{2}}$ & $\mathbf{T}_{\mathbf{3}}$ & $\mathbf{T}_{\mathbf{4}}$ \\
\hline $\mathrm{SRBC}\left(\log _{2}\right)$ & $6.67^{\mathrm{c}} \pm 0.33$ & $7.00^{\mathrm{bc}} \pm 0.58$ & $7.33^{\mathrm{bc}} \pm 0.33$ & $8.00^{\mathrm{b}} \pm 0.58$ & $7.67^{\mathrm{bc}} \pm 0.33$ & $9.67^{\mathrm{a}} \pm 0.33$ & 0.005 \\
$\mathrm{CBH}$ & $124.49 \pm 2.52$ & $111.67 \pm 2.67$ & $120.06 \pm 3.25$ & $116.15 \pm 2.17$ & $107.70 \pm 4.48$ & $121.84 \pm 8.32$ & 0.14 \\
\hline
\end{tabular}

Values bearing different superscripts in a row differ significantly $(p<0.05), S R B C=$ Sheep red blood cells, CBH=Cutaneous basophilc hypersensitivity

Table-5: Weight of lymphoid organs (percentage of live weight) of broiler.

\begin{tabular}{|c|c|c|c|c|c|c|c|}
\hline \multirow[t]{2}{*}{ Organs } & \multicolumn{6}{|c|}{ Treatments } & \multirow[t]{2}{*}{ p value } \\
\hline & $C_{1}$ & $C_{2}$ & $\mathbf{T}_{1}$ & $\mathbf{T}_{2}$ & $\mathbf{T}_{3}$ & $\mathbf{T}_{4}$ & \\
\hline Spleen & $0.084 \pm 0.007$ & $0.109 \pm 0.011$ & $0.117 \pm 0.004$ & $0.184 \pm 0.009$ & $0.166 \pm 0.061$ & $0.176 \pm 0.008$ & 0.09 \\
\hline Bursa & $0.188 \pm 0.054$ & $0.091 \pm 0.022$ & $0.127 \pm 0.029$ & $0.161 \pm 0.062$ & $0.194 \pm 0.058$ & $0.174 \pm 0.013$ & 0.56 \\
\hline Thymus & $0.517 \pm 0.086$ & $0.329 \pm 0.033$ & $0.541 \pm 0.123$ & $0.365 \pm 0.020$ & $0.577 \pm 0.152$ & $0.417 \pm 0.074$ & 0.38 \\
\hline
\end{tabular}

Table-6: Antioxidant enzyme and lipid peroxidation activity in broiler chicks.

\begin{tabular}{|c|c|c|c|c|c|c|c|}
\hline \multirow[t]{2}{*}{ Parameters (unit) } & \multicolumn{6}{|c|}{ Treatments } & \multirow[t]{2}{*}{ p value } \\
\hline & $\mathrm{C}_{1}$ & $\mathrm{C}_{2}$ & $T_{1}$ & $\mathbf{T}_{2}$ & $T_{3}$ & $\mathbf{T}_{4}$ & \\
\hline $\begin{array}{l}\text { Erythrocyte catalase } \\
\text { (units/mg of hemoglobin) }\end{array}$ & $1.27^{c} \pm 0.04$ & $1.34^{c} \pm 0.03$ & $1.90^{\mathrm{b}} \pm 0.07$ & $2.05^{\mathrm{b}} \pm 0.20$ & $2.94^{a} \pm 0.07$ & $3.13^{a} \pm 0.05$ & $<0.01$ \\
\hline $\begin{array}{l}\text { Erythrocyte MDA } \\
\text { (nmol MDA/mg of hemoglobin) }\end{array}$ & $2.01 \pm 0.15$ & $1.93 \pm 0.03$ & $1.95 \pm 0.16$ & $1.93 \pm 0.12$ & $1.97 \pm 0.14$ & $1.92 \pm 0.07$ & 0.99 \\
\hline
\end{tabular}

Values bearing different superscripts in a row differ significantly $(p<0.05)$, MDA=Malondialdehyde 


\section{Discussion}

The $\mathrm{CBH}$ response and antibody titers $\left(\log _{2}\right)$ against SRBC inoculation at $6^{\text {th }}$ week of age of broiler chicks is presented in Table-4. This implied that the CMI response in the Azolla supplemented groups was similar as that of the control groups. This is in agreement with the findings of Sujatha et al. [17]. The results implied that the $\mathrm{SRBC}$ response was better in groups having Azolla with enzyme supplementation. This is in agreement with the findings of Prabina and Kumar [18]. Dhumal et al. [1] reported that Azolla meal feeding in broiler improved the antibody titer values as compared to control group. This further corroborated the findings of Sujatha et al. [17] who reported higher mean hemagglutination inhibition titer against GRBC inoculation in the raw Azolla fed group than the control group. The weights of lymphoid organs (percentage of live weight) of Vencobb broiler chicks under different dietary treatments are presented in Table-5. The weight of lymphoid organs or immune organs of all the treated groups did not differ significantly $(\mathrm{p}>0.05)$. Supplementation of dietary protein from Azolla at 5\% or 10\% level with or without enzyme supplementation had no significant effect on the weight of lymphoid organs. In the available literatures, little evidence has been found regarding the CMI and humoral immune response, as well as, the weight of lymphoid organs in chicken in relation to Azolla supplementation in the diet.

The antioxidant enzyme and lipid peroxidation activity in broiler birds under different dietary treatments are presented in Table- 6 . The erythrocyte catalase level of $\mathrm{T}_{4}$ group was found to be significantly higher than the rest of the treated groups except $T_{3}$. Furthermore, erythrocyte catalase levels were found to be significantly $(p<0.05)$ higher than that of control groups. The increase in levels of erythrocyte catalase of broilers fed Azolla might be due to presence of iron and copper in Azolla as catalase is a heme-containing antioxidant enzyme, which acts sequentially to superoxide dismutase in the conversion of hydrogen peroxide to water [19]. Spears [20] reported that selenium, vitamin E, chromium, cobalt, copper, and vitamin A have immune regulatory properties in cattle.

$\mathrm{Fe}^{+3}$ protoporphyrin is the central catalase group. Catalase activity is reduced in $\mathrm{Cu}$ deficiency [21]. This is because $\mathrm{Cu}$ is necessary to adequate Fe utilization, which is an important component of catalase. Some researchers have reported an increase [22]; others have reported a decrease in erythrocyte catalase activity to be associated with copper deficiency [23]. Erythrocyte MDA (lipid peroxidation activity) levels did not differ significantly $(\mathrm{p}>0.05)$ between groups. Vitamins, recognized as a potent lipid-soluble antioxidant, have been found to play a key role in the normal functioning of the immune system and protects against lipid peroxidation of the cell membrane-initiated by free radicals by arresting or entirely preventing the process [24-27]. In spite of high fiber feeding in Azolla supplemented groups, due to presence vitamins along with other essential nutrients, no significant level of lipid peroxidation activity was observed in Azolla fed groups.

Moreover, the better immune response as observed in the present study might be the due presence of essential nutrients in Azolla relating to the immunity of the birds. Azolla is rich in protein, contains almost all essential amino acids, carotene, and several growth promoter intermediaries, and minerals such as calcium, phosphorus magnesium, potassium, iron, and copper [1]. Apart from nutrients, Azolla also contains certain compounds such as carotenoids, bio-polymers, and probiotics which contribute to higher productivity and health of animals [2].

\section{Conclusion}

From this, it may be concluded that replacement of soybean with Azolla, supplying 10\% of protein requirement along with enzyme supplementation in the isonitrogenous diet showed better immune response in broiler chickens.

\section{Authors' Contributions}

This study is a component of the work towards the M. V. Sc. thesis of the first author BC. GPM, CRP, SKM \& NCB: Provided guidance during the entire experiment. BC, SKM \& KB: Prepared and corrected the manuscript. AD: Helped in conducting the experiment and analysis of immunological parameters. All authors have read and approved the final version of the manuscript.

\section{Acknowledgments}

The authors are thankful to the Vice chancellor, Orissa University of Agriculture and Technology and Dean, College of Veterinary Science and Animal Husbandry, Orissa University of Agriculture and Technology, Bhubaneswar, Odisha for providing necessary facilities to conduct the research work. Department of Livestock Production \& Management, College of Veterinary Science and Animal Husbandry, Orissa University of Agriculture and Technology provided funds for carrying out the study.

\section{Competing Interests}

The authors declare that they have no competing interests.

\section{References}

1. Dhumal, M.V., Siddiqui, M.F., Siddiqui, M.B.A. and Avari, P.E. (2009) Performance of broilers fed on different levels of Azolla meal. Indian J. Poult. Sci., 44(1): 65-68.

2. Parashuramulu, S. and Nagalakshmi, D. (2012) Azolla A potential protein supplement for livestock. Livest. Line, 6(4): 18-21.

3. Balaji, K., Jalaludeen, A., Churchil, R.R., Peethambaran, P.A. and Senthilkumar, S. (2009) Effect of dietary inclusion of Azolla (Azolla pinnata) on production performance of broiler chicken. Indian J. Poult. Sci., 44(2): 195-198. 
4. Basak, B., Pramanik, M.A.H., Rahman, M.H., Tarafdar, S.U. and Roy, B.C. (2002) Azolla (Azolla pinnata) as a feed ingredient in broiler ration. Int. J. Poult. Sci., 1: 29-34.

5. Shamna, T.P., Peethambaran, P.A., Jalaludeen, A., Joseph, L. and Aslam,M.K.M.(2013)Broilercharacteristics ofJapanese quails (Coturnix coturnix japonica) at different levels of diet substitution with Azolla pinnata. Anim. Sci. Rep., 7(2): 75-80.

6. Calder, P.C. and Kew, S. (2002) The immune system: A target for functional foods? Br. J. Nutr., 88(2): S165-S177.

7. Nayak, N., Padhy, R.N. and Singh, P.K. (2015) Evaluation of antibacterial and antioxidant efficacy of the fern Azolla caroliniana symbiotic with the cyanobacterium Anabaena azollae. Proc. Natl. Acad. Sci., India, Sect. B Biol. Sci., 85(2): 555-569.

8. Noor Nawaz, A.S., Syed, J., Dileep, N., Rakesh, K.N. and Prashith Kekuda, T.R. (2014) Antioxidant activity of Azolla Pinnata and Azolla Rubra - A comparative study. Sch. Acad. J. Biosci., 2(10): 719-723.

9. Kumar, A., Kumari, J., Kumar, H., Nath, A., Singh, J.K., Ali, M. and Kumar, R. (2014) Hepatoprotective and antioxidant effect of Azolla filiculoides on profenofos induced hepatotoxicity in Swiss albino mice. Caribb. J. Sci. Technol., 2: 372-377.

10. Edelman, A.S., Sachez, P.I., Robinson, M.E., Hochwalad, G.M. and Thorbecke, G.J. (1986) Primary and secondary swelling response to phytohaemagglutinin as a measure of immune competence in chickens. Avian Dis., 30: 105-111.

11. Soni, N., Mishra, S.K., Swain, R., Das, A., Chichilichi, B. and Sethy, K. (2013) Bioavailability and immunity response in broiler breeders on organically complexed zinc supplementation. Food Nutr. Sci., 4: 1293-1300.

12. Abdallah, A.G., El-Husseiny, O.M. and Abdel-Latif, K.O. (2009) Influence of some dietary organic mineral supplementations on broiler performance. Int. J. Poult. Sci., 8(3): 291-298.

13. Yagi, Y., Furunchi, S., Takashi, H. and Koyama, H. (1989) Abnormality of osmotic fragality and morphological disorder of bovine erythrocytes infected with Theileria sergenti. Jpn. J. Vet. Sci., 51: 389-395.

14. Bergmeyer, H.U. (1983) UV method of catalase assay. In:
Methods of Enzymatic Analysis. Vol. 3. Bansal, Weinheim Deer Field Beach, Florida. p273.

15. Placer, Z.A., Cushman, L.L. and Johnson, B. (1966) Estimation of product of lipid peroxidation (malonaldehyde) in biochemical system. Anal. Biochem., 16: 359-364.

16. Snedecor, G.W. and Cochran, W.G. (1998) Statistical Methods. $6^{\text {th }}$ ed. Oxford and IBH Publishing Company, Kolkata, India.

17. Sujatha, T., Udhayakumari, D., Kundu, A., Jeyakumar, S., Sundar, J. and Kundu, M.S. (2013) Utilization of raw azolla as a natural feed additive for sustainable production in Nicobari fowl. Anim. Sci. Rep., 7(4): 146-152.

18. Prabina, B.J. and Kumar, K. (2010) Dried Azolla as a nutritionally rich cost effective and immuno-modulatory feed supplement for broilers. Asian J. Anim. Sci., 5(1): 20-22.

19. Cohen, G., Dembiec, D. and Marcus. J. (1970) Measurement of catalase activity in tissue extracts. Anal. Biochem., 34: 30-38.

20. Spears, J.W. (2000) Micronutrients and immune function in cattle. Proc. Nutr. Soc., 59: 587-594.

21. Lai, C., Huang, W., Askari, A., Klevay, L.M. and Chiu, T.H. (1995) Expression of glutathione peroxidase and catalase in copper deficient rat liver and heart. J. Nutr. Biochem., 6: 256-262.

22. Bozkaya, L.A., Ozturk-Urek, R., Aydemir, T. and Tarhan, L. (2001) Effects of $\mathrm{Se}, \mathrm{Cu}$ and $\mathrm{Se}+$ Vitamin E deficiency on the activities of CuZn-SOD, GSH-Px, CAT and LPO levels in chicken erythrocytes. Cell Biochem. Funct., 19: 153-157.

23. Chevar, S., Andial, T. and Banke, K. (1992) Free radical reactions and cancer. Vopr. Med. Khim., 5: 4-5.

24. Tappel, A.L. (1970) Biological antioxidant protection against lipid peroxide damage. Am. J. Clin. Nutr., 23: 1137-1139.

25. Meydani, S.N. and Beharka, A.A. (1996) Recent developments in vitamin $\mathrm{E}$ and immune response. Nutr. Rev., 56: S49-S58.

26. Moriguchi, S. and Muraga, M. (2000) Vitamin E and immunity. Vitam. Horm., 59: 305-336.

27. Spears, J.W. and Weiss, W.P. (2008) Role of antioxidants and trace minerals in health and immunity of transition dairy cows. Vet. J., 176: 70-76.

$* * * * * * * *$ 